by the Society; formerly a correspondent in London or Paris, \&c., sent a general account of chemical work published in the country from which he wrote. The abstracts of the German Society are on the whole shorter than those which have for many years made the Journal of our own Chemical Society of such great value to the student; they are, however, published at a shorter interval after the appearance of the original paper.

Brief accounts are given of recent chemical patents, but little space is devoted to purely technical chemistry. Is not the fournal of the Chemical Society sometimes overburdened by abstracts which might better find a place in a book professing to collect receipts for the purely "practical man"?

The German Chemical Society in 1877 appointed Dr. C. Bischof of Berlin to prepare a general index for the first ten volumes of the Berichte. The arduous task has been admirably fulfilled. Fellows of the Society have now in their hands not only an index to the Berichte, but a volume which is really a general guide to the chemical work published during the period 1868-I 877 .

The "Generalregister" extends to Iozo pp.; of these, $162 \mathrm{pp}$. are devoted to an index of authors, $732 \mathrm{pp}$. to an index of subjects, $42 \mathrm{pp}$. to an index of patents, and 84 $\mathrm{pp}$. to a systematic classification of the carbon compounds referred to in the index.

Under an author's name are given, not the exact title of his paper, but a very succinct statement of the leading points in the paper. The same method is pursued in the subjects-index. Taking, for instance, such a general subject as "Dissociation," one finds, first, references to work on the general Theory of Dissociation, e.g. connection between dissociation and temperature, tension, \&c. ; then follow special instances of dissociation, inorganic compounds preceding organic. In the case of individual elements or compounds, the references begin with those papers on the existence of the substance in question, then follow its preparation and formation, its properties, its action on other substances, the action of other bodies on it, its estimation, \&c., \&c.

A systematic nomenclature is adopted, more especially for the carbon compounds: the principles which guided the compiler are stated in a few introductory pages.

The "Generalregister" cannot but be of the greatest value to chemists generally. Almost every chemist is a Fellow of the German Society; many possess the Berichte complete up to date; with the Berichte and this admirable guide which Dr. Bischof has supplied, they can find almost everything that has been done in experimental chemistry within the period $1868-1877$. M. M. P. M.

\section{IRISH ESPARTO GRASS}

$\mathrm{T} \mathrm{T}$ is now over two years ago since attention was called in our pages to the importance of the purple Molinia (Molinia carulea) as a material for making paper. Mr. Christie of Edinburgh sent a small quantity of it to be operated on by Mr. T. Routledge of Sunderland, and the report on this was most favourable. In January, 1879, a notice appeared in the Times also calling attention to the subject, and referring to the above favourable report; it expressed the hope that some effort would be used to have this grass collected on an extensive scale. It would seem to be ripe for gathering in the early autumn, when some hands could be spared for such work, and as the ground on which it flourishes - wet or partially drained bogs-pays, at least in Ireland, little if any rent, the crop would cost little over the expense of reaping it. Since the first notice appeared in our columns, the Spanish and African Esparto grass has been getting more difficult to obtain, and the demand for it has been steadily on the increase. It is said that the greater part of what is gathered in Morocco finds its way to the Times papermills, and its value for paper-making is now known in
America. Several analyses of specimens of the dried hay made from this grass are given in a paper by Dr. Cameron, "On the Composition of a Crop of Hay" (Proc. Roy. Dub. Soc., n.s., vol. ii. p. IOI); we select one of these, which yielded as follows :-

\section{0 parts contained-}

$\begin{array}{lccccr}\text { Water } \ldots & \ldots & \ldots & \ldots & \ldots & 27 \cdot 95 \\ \text { Albuminoids } & \ldots & \ldots & \ldots & \ldots & 7 \cdot 49 \\ \text { Fats } \ldots & \ldots & \ldots & \ldots & \ldots & 2 \cdot 70 \\ \text { Non-nitrogenous } & \text { substances } & \ldots & \ldots & 30^{\circ} \circ 0 \\ \text { Woody fibre } & \ldots & \ldots & \ldots & \ldots & 31 \cdot 26 \\ \text { Mineral water } & \ldots & \ldots & \ldots & \ldots & 0.60 \\ & & & & & \text { 100.00 }\end{array}$

\begin{tabular}{|c|c|c|c|c|c|c|}
\hline \multicolumn{7}{|c|}{ And of this the ash contained- } \\
\hline Lime & $\ldots$ & $\ldots$ & $\ldots$ & $\ldots$ & $\ldots$ & $28 \cdot 86$ \\
\hline Magnesia & $\ldots$ & $\ldots$ & $\ldots$ & $\ldots$ & $\ldots$ & $4 \cdot 76$ \\
\hline Potash an & d soda & .... & $\ldots$ & $\ldots$ & $\ldots$ & $42 \cdot 17$ \\
\hline Phosphor & ic acid & $\ldots$ & $\ldots$ & $\ldots$ & $\ldots$ & $12 \cdot 36$ \\
\hline Sulphuric & acid & & $\ldots$ & $\ldots$ & $\ldots$ & 5.98 \\
\hline Oxide of & iron an & d al & ina & $\ldots$ & $\ldots$ & $1 \cdot \infty$ \\
\hline Chlorine & $\ldots$ & $\ldots$ & $\ldots$ & $\ldots$ & $\ldots$ & $4 \cdot 32$ \\
\hline Silica & $\ldots$ & $\ldots$ & $\ldots$ & $\ldots$ & $\ldots$ & 0.55 \\
\hline
\end{tabular}

This freedom from silica of the purple Melic grass is very remarkable.

From a paper by Mr. W. Smith in the recent number of the Proceedings of the Royal Dublin Society, we learn that a very successful trial has been made in the county of Galway to grow this grass in some quantity. As a native plant it is found in every county in Ireland, both on wet heaths and boggy pastures. It flowers in July and August, and its seeds are ripe early in September; it would seem to grow well on partially drained bogs, and if the surface of these has been burnt, the purple Melic grass grows thereon most luxuriantly. It seems fond of growing in tufts, of somewhat large size, and it does not form a sod like so many other grasses. It would appear that in Ireland alone there are over $1,000,000$ acres at the present moment not worth sixpence a year each for any agricultural purpose ; each acre would easily grow half a ton weight of dried Melic grass, which at its lowest value would be worth $2 l$. Would not this crop, in time, more than compensate for the loss of the potatoe? It seems a pity that the manufacturer should have to go to the Port of Mogador for what he might get with so much greater ease at the Port of Dublin.

\section{SIBERIAN METEOROLOGY}

U $\mathrm{P}$ to the present time Yakutsk, in North-east Siberia, has often been cited as the place of our earth where the winter is coldest, while the minima observed during Arctic expeditions are believed to be the lowest known. Neither the one nor the other is true. In Maak's book, "Olekminski Okrug," I find many data which prove that the coldest winter as well as the lowest well-authenticated minima were observed at Werkhojansk, to the north-east of Yakutsk. The name of the author gives us some guarantee that the observations are trustworthy. I give below the minima at some places cited by Maak, and compare them with those observed in Central and Western Siberia, and the Arctic Archipelago of America:-

\section{North-East Siberia}

Serdze-Kamen. $67^{\circ}$ N. $173^{\circ}$ E. (Nordenskjöld) $-50^{\circ} 3 \mathrm{~F}$.

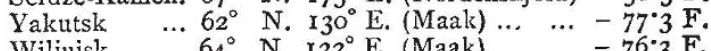

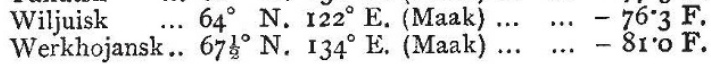

$$
\text { Central and West Siberia }
$$

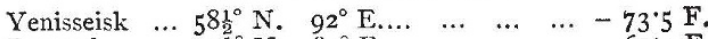

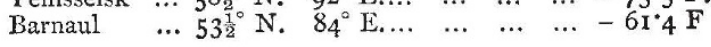




\section{Arctic Archipelago}

British Expedi- $\left\{83 \frac{1}{2}^{\circ} \mathrm{N}\right.$. Floeberg Reach (Nares) - 73.7 F. tions, $1875-76$. $381 \frac{1}{2}^{\circ} \mathrm{N}$. Discovery Bay (Nares) $-70^{\circ} 7 \mathrm{~F}$.

The temperature at Werkhojansk is the lowest of all given here, and it must be borne in mind that the observations lasted but one year, while we have more than thirty-five years at Yakutsk, and eight and a half at Yenisseisk.

The mean temperatures are as follows :-

\begin{tabular}{|c|c|c|c|c|c|c|c|}
\hline & Year & July & Nov. & Dec. & Jan. & Feb. & March \\
\hline $\begin{array}{l}\text { Ustjansk } 2 \text { years } \\
\text { Werkhojansk I year } \\
\text { Yakutsk 10 years I } \\
\text { Yakutsk } 24 \text { years }{ }^{2} \\
\text { Floeberg Beach I yr. } \\
\text { Discovery Bay } 1 \text { yr. }\end{array}$ & $\begin{array}{r}- \\
2 \cdot 8 \\
4.3 \\
12.2 \\
12.4 \\
-\quad 3.5 \\
-4.2\end{array}$ & $\begin{array}{l}-\overline{-} \\
52^{*} \cdot 7 \\
60 \cdot 1 \\
66 \cdot 5 \\
63 \cdot 3 \\
38 \cdot 3 \\
37^{\circ} \cdot 2\end{array}$ & $\begin{array}{r}2.1 \\
-\quad 2.2 \\
-29^{\circ} 2 \\
-20^{\circ} 5 \\
-19.1 \\
-16.8 \\
-18.4\end{array}$ & $\begin{array}{l}-90^{\circ} \\
-33^{\circ} \circ \\
-46.8 \\
-41.9 \\
-37^{\circ} 8 \\
-22.2 \\
-24^{\circ} 5\end{array}$ & $\begin{array}{l}-13.1 \\
-38.9 \\
-55^{\circ} .5 \\
-46.8 \\
-41^{\circ} .4 \\
-33^{\circ} 0 \\
-40^{\circ} 7\end{array}$ & $\begin{array}{l}-13.2 \\
-36.9 \\
-54.5 \\
-37.7 \\
-30^{\circ} 8 \\
-38.0 \\
-35^{\circ} \circ\end{array}$ & $\begin{array}{l}-6.9 \\
-175 \\
-29.0 \\
-0.0 \\
-8.7 \\
-39.8 \\
-374\end{array}$ \\
\hline
\end{tabular}

Though the observations were made only during one year at Werkhojansk, it is probable that it would have the coldest winter of all observed till now, as even at Yakutsk, which is the next coldest, January and February were in no single year colder than at Werkhojansk in 1869. From a comparison with the other stations of North-east Siberia it is probable that here in 1869 February was too cold and December too warm.

Now as to the reason why the winter should be colder in North-east Siberia than on the North American Archipelago farther to the north, it is to be found in the extent of the continent, the distance from any sea open in winter, and the prevailing calms. How important is the last reason is best seen by the comparison of the December and January temperatures of the last British expedition. The more northerly Floeberg Beach is warmer, because more exposed to winds. Now in Eastern Siberia calms prevail to a large extent in winter, except near the coast.

There is a phenomenon to be considered, which is noticed everywhere in winter in high latitudes: during calms with clear sky the valleys are colder than the surrounding hills and slopes, because the cold air sinks downwards and stagnates there. This is confined to the night where the mid-day sun rises high enough, but in high latitudes during some months the mid-day heat of the sun is too small and the day too short to interfere much with the equilibrium of the strata of air established during the night. Even in middle latitudes $\left(45^{\circ}-50^{\circ}\right)$, when calms and clear weather prevail very largely in December, the valleys are regularly colder than the hills. So it was felt in December, 1879, in Central Europe. What is en exception here is the rule in North-East Siberia, because calms and clear sky are the rule in winter; the valleys are much co!c'cr than the hills. On this account the exceedingly low temperature of Werkhojansk in winter is probably not common to the whole surrounding country, and especially in the mountains rising to a short distance south we may expect a much higher temperature. The more we consider the conditions of the winter temperature of North-East Siberia, the more difficult it seems to draw isotherms. We know that plains and valleys there are colder than hills and mountain-slopes, but how much, and what conditions are most favourable to that so-called interversion of temperature? I consider it as highly probable that both at Yakutsk and at Werkhojansk the local topographical conditions are very favourable to winter cold. This being the case, it is quite natural that the latter place is colder in winter than the former, being situated $5^{\circ}$ farther to the north, and yet far enough from the west to have a continental climate.

A. WOEIKOF

\section{SPHYGMOGRAPHY}

THE pulse has in all ages been held by physicians to be a valuable aid to the diagnosis of disease, but until the invention of the sphygmograph, or pulse-writer, the determination of the character of the pulse was left to the tutored tact of the doctor's finger, which varies much in delicacy of perception in different operators, and in the same practitioner at different times. At most the finger, even of the most experienced, can only detect, regarding the pulse, that it is soft or hard, quick or slow, jerky or lariguid, regular or irregular; but the finger is incapable of analysing the beats, and detecting any departure from the normal standard of each of their component elements. The sphygmograph, which is quite a modern invention, causes the pulse to write its own autograph, enables us to see at a glance the peculiar characters of the pulse, and to ascertain how and where it differs from the healthy or normal pulse.

Hitherto, however, the sphygmograph has been but little used, for those that have been introduced are large and expensive instruments, requiring a great amount of skill and trouble to fix them on the arm and bring them into action; and for these reasons they are not available for general or private practice. Hence their use has almost been confined to hospital practice; but even here

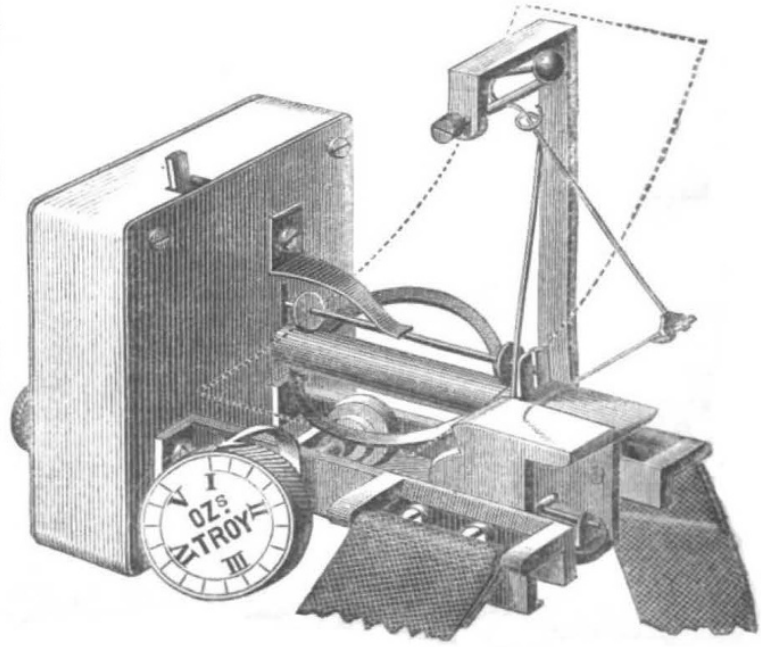

they are not always available, for Dr. B. Bramwell, who is a strong advocate for employing the sphygmograph, relates that a patient of his was so terrified by the proposal to employ the instrument that he preferred leaving the hospital to allowing it to be fixed on his arm.

The objections to the general use of the sphygmograph do not apply to the instrument recently introduced into medical practice by Dr. Dudgeon, and from its portability called "the pocket sphygmograph." 'Though this instrument is so small as to deserve the name of "pocket," it is not inferior in sensitiveness to the most elaborate and complicated of the cumbrous instruments hitherto in use, indeed in some respects it is greatly superior in accuracy to any that have yet appeared. Its size is $2 \frac{1}{2}$ by 2 inches; its weight only four ounces. It magnifies the movements of the artery exactly fifty times. The spring that presses on the artery can be regulated to press with a weight of from one to five ounces, and the pressure can be altered at will while the instrument is in situ. It requires no wrist-rest; all the other sphygmographs have to be used with wrist-rests of more or less complexity. It can be used with equal facility whether the patient is standing, sitting, or lying. With it an accurate and extremely distinct tracing of the pulse can be made almost as quickly as the pulse can be felt with the finger. Its

\footnotetext{
I According to Maak.

2 Older series of Neverof (1829-54).
} 